\title{
Uji Antibakteri Ekstrak Kulit Buah Pisang Kepok (Musa paradisiaca $x$ balbisiana) Mentah Terhadap Pertumbuhan Bakteri Staphylococcus aureus
}

\section{Antibacterial Teest of Musa paradisiaca x balbisiana Peel Extract against the Growth of Staphylococcus aureus}

\author{
Herdimas Yudha Pratama ${ }^{1)}$, Ernawati ${ }^{2)^{*}}$, Nur R.Adawiyah Mahmud ${ }^{3)}$ \\ ${ }^{1,2,3)}$ Prodi Pendidikan Biologi, FKIP, Universitas Muhammadiyah Kupang
}

Received $17^{\text {th }}$ July $2018 /$ Accepted $20^{\text {th }}$ September 2018

\begin{abstract}
ABSTRAK
Penelitian ini bertujuan untuk mengetahui aktivitas ekstrak kulit buah mentah pisang kepok (Musa paradisiaca x balbisiana) sebagai antibakteri alami dalam menghambat pertumbuhan bakteri Staphylococcus aureus, dan mengetahui konsentrasi ekstrak kulit buah mentah pisang kepok (Musa paradisiaca $x$ balbisiana) yang paling baik dalam menghambat pertumbuhan bakteri Staphylococcus aureus. Eksperimen terdiri dari 5 perlakuan dan 3 kali ulangan yaitu kontrol perlakuan, perlakuan $1(P 1)=$ Konsentrasi 25\% (0,5 mg/2ml aquades), $P 2=$ Konsentrasi 50\% ( $1 \mathrm{mg} / 2 \mathrm{ml}$ aquades), $P 3=$ Konsentrasi $75 \%$ (1,5 mg/2 ml aquades), P4=100\% (2 $\mathrm{mg} / 2 \mathrm{ml}$ aquades). Parameter yang diukur dalam penelitian ini adalah jumlah koloni bakteri Staphylococcus aureus. Data dianalisis dengan menggunakan Standar Plate Count (SPC). Hasil penelitian menunjukkan bahwa ekstrak kulit buah pisang kepok mentah mampu menghambat pertumbuhan bakteri Staphylococcus aureus. Perlakuan dengan konsentrasi $100 \%$ merupakan perlakuan paling baik dalam menghambat pertumbuhan bakteri Staphylococcus aureus dengan jumlah koloni terendah yaitu $8,7 \times 10^{4}$ koloni.
\end{abstract}

Kata kunci: Musa paradisiaca x balbisiana, antibakteri, Staphylococcus aureus.

\begin{abstract}
Antibacterial activity of crude extract of pisang kepok raw fruit peel (Musa paradisiaca $x$ balbisiana) were tested against Staphylococcus aureus. This research was designed with 5 treatments and 3 replications. Various concentration of sample extract that has been given are P0: 0\%, P1: 25\% (0.5 mg/2 ml), P3: 50\% (1 mg/2 ml), P4: 75\% $(1.5 \mathrm{mg} / 2 \mathrm{ml})$, and P5: $100 \%(2 \mathrm{mg} / 2 \mathrm{ml})$, in aqueous solution. The result shows the potential of sample extract to inhibit the growth of Staphylococcus aureus. P5 shows the
\end{abstract}

*Korespondensi:

email:ewati0792@gmail.com 
best result in inhibit Staphylococcus aureus growth with the lowest colony count i.e. 8.7 $x 10^{4}$ colonies.

Keywords: Musa paradisiaca x balbisiana, antibacteri, Staphylococcus aureus.

\section{PENDAHULUAN}

Bakteri Staphylococcus sering ditemukan sebagai mikroflora normal pada kulit dan selaput lendir pada manusia (Yeni dkk, 2010) dan merupakan penyebab penyakit pada manusia yang terdapat pada beberapa bagian tubuh manusia seperti diare, berbagai infeksi seperti infeksi pada luka, infeksi folikel rambut, meningitis dan pneumonia (Supartono, 2006).

Upaya pengendalian terhadap bakteri Stahylococcus aureus telah banyak dilakukan terbukti dengan adanya antibiotik. Namun sejauh ini antibiotik seperti penisilin G, ampisilin, amoksilin, tetraksilin dan kloramfenikol dapat menyebabkan resistensi bila digunakan dalam jangka waktu lama. Sehingga diperlukan penemuan antibiotik yang lebih aman mudah serta hemat biaya. Akibat timbulnya resistensi pada antibiotik maka saat ini ditemukan obat tradisional dari beberapa tumbuhan yang mampu menyembuhkan penyakit diantaranya kulit pisang..

Kulit pisang merupakan salah satu tanaman yang banyak digunakan masyarakat di negara berkembang sebagai obat tradisional. Kulit pisang memiliki kandungan fenolik dan bahan aktif seperti tanin dan flavonoid (Wardini dkk, 2017). Kandungan tanin lebih banyak terdapat pada kulit buah pisang yang belum matang, karena terjadinya peningkatan etanol hingga 70 kali lipat, pada proses pematangan pisang menyebabkan turunnya kandungan tanin. Pada daging buah pisang mengandung rata-rata $11,21 \%$ flavonoid dan 24,6\% pada kulit pisang (Dinastuti dkk, 2015).

Hasil penelitian Noorhamdani dkk, (2012) menunjukkan bahwa senyawa tanin dan flavonoid yang terdapat dalam kulit pisang ambon muda berpotensi sebagai antibakteri terhadap bakteri Escherichia coli. Hal ini menunjukkan bahwa kulit pisang memiliki kandungan antibakteri sehingga memungkinkan untuk dijadikan antibiotik terhadap infeksi bakteri Staphylococcus aureus.

\section{METODE PENELITIAN}

Alat dan bahan dalam penelitian ini dipersiapkan di Laboratorium. Kultur murni bakteri Staphylococcus aureus di peroleh dari Laboratorium Pendidikan Biologi Universitas Nusa Cendana Kupang. Sedangkan kulit buah pisang kepok (Musa paradisiaca $x$ balbisiana) mentah di peroleh dari pasar inpres kota Kupang.

\section{Proses Pembuatan Ekstrak Kulit buah mentah pisang kepok Muda}

Kulit buah mentah pisang kepok muda (Musa paradisiaca $x$ balbisiana) diambil dan dicuci bersih. Selanjutnya dikeringkan sampai kulit pisang benar - benar kering (bebas kandungan air), setelah proses pengeringan kulit pisang dihaluskan, selanjutnya serbuk halus kulit buah mentah pisang kepok diekstraksi menggunakan metode maserasi dengan 
pelarut etanol $70 \%$ selama 3 x 24 jam. Kemudian kulit buah mentah pisang kepok dievaporasi menggunakan rotary evaporator untuk mendapat ekstrak kental Kulit buah mentah pisang kepok.

\section{Uji Aktivitas Antibakteri Kulit buah mentah pisang kepok}

Siapkan 6 tabung reaksi yang sudah diisi dengan $9 \mathrm{ml} \mathrm{NaCl}$ ke dalam setiap tabung. Kemudian dari tabung yang sudah diukur $\left(1.5 \times 10^{8} \mathrm{CFU} / \mathrm{ML}\right)$ diambil $1 \mathrm{ml}$. suspensi S.aureus lalu dicampur dengan pengenceran $1\left(10^{-1}\right)$ dan dihomogenkan.. dari tabung 1 diambil $1 \mathrm{ml}$ kemudian dipindahkan ke tabung pengenceran $2\left(10^{-2}\right)$ dari tabung 2 diambil $1 \mathrm{ml}$ dipindahkan ke tabung pengenceran $3\left(10^{-3}\right)$. Dan seterusnya hingga tabung terakhir dari seri pengenceran.

Stelah itu, ambil $0,1 \mathrm{ml}$ suspense pada tabung pengenceran terakhir $\left(\left(10^{-6}\right)\right.$ sampai pengenceran $10^{-2}$ dan diteteskan ke cawan petri untuk ditanam di media dengan metode spread plate, lalu diinkubasi selama 24 jam pada suhu $37^{\circ} \mathrm{C}$. pengamatan dengan menghitung jumlah koloni yang tumbuh yang dipilih jumlah koloni 30-300 koloni bakteri. Siapkan lima tabung untuk variasi konsentrasi larutan uji 25\%, 50\%, 75\% dan $100 \%$. Masing-masing konsentrasi ekstrak kulit buah pisang kepok mentah diambil dan ditambah masing-masing $0.5 \mathrm{ml}$ bakteri uji. Kemudian divortex lalu diinkubasi selama 24 jam, suhu $37^{\circ} \mathrm{C}$. Setelah diinkubasi dari setiap tabung diambil $0.1 \mathrm{ml}$ dan diteteskan dalam media NA untuk ditanam dan diinkubasi selama 48 jam. Setelah 48 jam dilakukan perhitungan koloni Staphylococcus aureus pada koloni counter. Data yang di peroleh di analisis secara deskriptif menggunakan Standar Plate Count (SPC).

\section{HASIL DAN PEMBAHASAN}

Metode penentuan aktivitas antibakteri ekstrak kulit pisang kepok menggunakan metode pengenceran bertingkat. Metode perhitungan jumlah bakteri menggunakan Standar Plate Count (SPC) . Hasil pengenceran bertingkat yang dilakukan pada suspensi Staphylococcus aureus pada tingkat pengenceran $10^{-2}$-sampai $10^{-6}$ diperoleh hasil jumlah koloni yang memenuhi syarat koloni 30-300 koloni dan hasil bagi dari jumlah koloni pengenceran tertinggi dan terendah, maka jumlah yang dilaporkan adalah cawan dengen pengenceran terendah adalah pengenceran $10^{-5}$ yang dapat digunakan untuk uji sampel dengan metode Standard Plate Count (SPC). Hasil analisis jumlah koloni bakteri Staphylococcus aureus berdasarakan Standard Plate Count disajikan pada tabel 1.

Tabel 1. Hasil analisis Standar Plate Count (SPC)

\begin{tabular}{ccccc}
\hline Perlakuan & Ulangan & & $\begin{array}{c}\text { Rata-rata } \\
\text { (CFU/mL) }\end{array}$ \\
\hline & $\mathbf{1}$ & $\mathbf{2}$ & $\mathbf{3}$ & \\
\hline 0 & $2.0 \times 10^{6}$ & $1.9 \times 10^{6}$ & $1.8 \times 10^{6}$ & $1.9 \times 10^{6}$ \\
25 & $1.7 \times 10^{6}$ & $1.7 \times 10^{6}$ & $1.6 \times 10^{6}$ & $1.7 \times 10^{6}$ \\
50 & $1.5 \times 10^{6}$ & $1.4 \times 10^{6}$ & $1.4 \times 10^{6}$ & $1.4 \times 10^{6}$ \\
75 & $1.3 \times 10^{6}$ & $1.3 \times 10^{6}$ & $1.1 \times 10^{6}$ & $1.2 \times 10^{6}$ \\
100 & $1.1 \times 10^{6}$ & $9.9 \times 10^{5}$ & $5.5 \times 10^{5}$ & $8,8 \times 10^{5}$ \\
\hline
\end{tabular}

(Sumber data primer diolah, 2017) 
Berdasarkan tabel 1, terlihat bahwa uji antibakteri ekstrak kulit buah pisang kepok (Musa paradisiaca $x$ balbisiana) mentah terhadap pertumbuhan bakteri Staphylococcus aureus, menunjukan pada semua perlakuan yang diuji mampu menghambat pertumbuhan bakteri Staphylococcus aureus, hal ini ditunjukkan dengan menurunnya jumlah koloni pada setiap konsentrasi perlakuan jika dibandingkan dengan kontrol.

\section{Pembahasan}

Penelitian ini menggunakan kontrol perlakuan sebagai pembanding yaitu akuades. Akuades sebagai kontrol tidak memiliki zat antibakteri sama sekali sehingga tidak mempunyai daya hambat dan memiliki pH 7 sehingga Staphylococcus aureus dapat tumbuh bebas dengan jumlah koloni yang tumbuh lebih banyak dibandingkan jumlah koloni pada kelompok perlakuan. Hasil perhitungan rata-rata jumlah koloni Staphylococcus aureus yang tumbuh secara berurutan pada konsentrasi 25\%, 50\%, 75\%, $100 \%$, dan kontrol yaitu $1.7 \times 10^{6} \mathrm{CFU} / \mathrm{ml}, 1.4 \times 10^{6} \mathrm{CFU} / \mathrm{ml}, 1.2 \times 10^{6} \mathrm{CFU} / \mathrm{ml}$, dan 8.8 $\mathrm{x} 10^{5} \mathrm{CFU} / \mathrm{ml}$.

Berdasarkan hasil penelitian tersebut menunjukkan bahwa ekstrak kulit buah pisang kepok (Musa paradisiaca $x$ balbisiana) mentah mampu menghambat pertumbuhan bakteri Staphylococcus aureus.Adanya kemampuan ekstrak kulit buah pisang kepok (Musa paradisiaca $x$ balbisiana) mentah dalam menghambat pertumbuhan bakteri Staphylococcus aureus dikarenakan adanya senyawa antibakteri pada kulit buah pisang kepok (Musa paradisiaca x balbisiana) yang mampu menghambat serta membunuh bakteri. Menurut Wardini dkk, (2017) bahwa kulit buah pisang memiliki kandungan fenolik dan bahan aktif seperti tanin dan flavanoid, tanaman yang mengandung tanin dan flavonoid bersifat antiseptik dan dapat digunakan sebagai antibakteri (Sari dkk, 2010), kemudian menurut Paju dkk, (2013) Antibakteri merupakan zat yang dapat menghambat atau membunuh bakteri dengan penyebab infeksi. Diantara bakteri yang dapat menyebabkan infeksi adalah Staphylococcus aureus.

Menurut Masduki, (1996) dalam Ajizah, (2004) bahwa tanin mempunyai daya antibakteri dengan cara mempresipitasi, karena diduga tannin mempunyai efek yang sama dengan senyawa fenolik. Efek antibakteri tanin antara lain melalui reaksi dengan membran sel, inaktivasi enzim, dan destruksi atau inaktivasi fungsi materi genetik. Menurut Azhari, (2014) tanin merupakan senyawa fenol berfungsi untuk menghambat pertumbuhan bakteri denganmemunculkan denaturasi protein dan menurunkan tegangan permukaan, sehingga permeabilitas bakteri meningkat serta menurunkan konsentrasi ion kalsium, menghambat produksi enzim, dan mengganggu proses reaksi enzimatis pada bakteri Staphylococcus aureus sehingga menghambat terjadinya koagulasi plasma yang diperlukan oleh Staphylococcus aureus. Menurut Wistreich dan Lechtman dalam Azhari, (2014) kerusakan dan peningkatan permeabilitas sel bakteri menyebabkan pertumbuhan sel terhambat dan akhirnya dapat menyebabkan kematian sel.

Zat antibakteri lain yang ada pada kulit buah pisang kepok adalah flavanoid, flavonoid merupakan senyawa fenol yang bersifat koagulator protein pada bakteri. Protein yang terkoagulasi ini adalah protein yang mengalami denaturasi dan tidak dapat 
berfungsi dalam sintesis protein yang akhirnya menyebabkan bakteri mati (Mubarak, 2016). Flavonoid juga mampu berinteraksi dengan DNA bakteri. Hasil interaksi ini menyebabkan terjadinya kerusakan permeabilitas dinding sel bakteri, mikrosom, dan lisosom (Sabir, 2003).

Flavonoid mempunyai kemampuan berinteraksi dengan DNA bakteri serta menghambat fungsi membran sitoplasma bakteri dimana pada akhirnya akan mengalami kerusakan pada permeabilitas dinding sel bakteri membran. Flavonoid juga dapat menjadi inhibitor enzim sehingga bakteri tidak dapat memproduksi enzim dengan baik (Azhari, 2014).

\section{KESIMPULAN}

Antibakteri ekstrak kulit buah mentah pisang kepok (Musa paradisiaca x balbisiana) mampu menghambat pertumbuhan bakteri Staphylococcus aureus. Konsentrasi ekstrak kulit buah mentah pisang kepok (Musa paradisiaca $x$ balbisiana) yang paling baik dalam menghambat pertumbuhan bakteri Staphylococcus aureus adalah pada konsentrasi $100 \%$.

\section{DAFTAR PUSTAKA}

Azhari, Taufik. 2014. Uji Efektivitas Ekstrak Daun Salam (Eugenia polyantha) Terhadap Pertumbuhan Staphylococcus aureus Secara In Vitro. [Skripsi]. Makassar: Universitas Hasanuddin.

Dinastuti, Rina, Sri Poeranto Y.S., dan Dwi Yuni Nur Hidayati. (2015). Uji Efektifitas Antifungal Ekstrak Kulit Pisang Kepok (Musa acuminata x balbisiana) Mentah Terhadap Pertumbuhan Candida albicans Secara In Vitro. Majalah Kesehatan FKUB. 2 (3).

Mubarak, Z., Santi Chismirina, dan Hafizah H. Daulay. 2016. Aktivitas Antibakteri Ekstrak Propolis Alami Dari SarangLebah Terhadap Pertumbuhan Enterococcus faecalis. Journal of Syiah Kuala Dentistry Society. 1 (2): 175-186.

Ningsih, A. P., Nurmiati, dan A. Agustien. 2013. Uji Aktivitas Antibakteri Ekstrak Kental Tanaman Pisang Kepok Kuning (Musa paradisiaca Linn.) terhadap Staphylococcus aureus dan Escherichia coli. Jurnal Biologi Universitas Andalas. 2 (3): 207-213.

Noorhamdani, Permatasari Nur, Minerva Annie. 2012. Ekstrak Metanol Kulit Pisang Ambon Muda (Musa paradisiaca L.) Sebagai Antimikroba Terhadap Bakteri Escherichia coli Secara In Vitro. Mikrobiologi FKUB. 2 (3):73-80.

Noormayunita, S., S. Anam, dan A. Khumaidi. 2015. Aktivitas Antibakteri Fraksi Ekstrak Kulit Buah Mentah Pisang Ambon (Musa paradisiaca var.sapientum) Terhadap Staphylococcus aureus. Jurnal of Natural Science, 4 (3): 300-309.

Nur, Jumriah, Zaraswati Dwyana, As'adi Abdullah. 2013. Bioaktivitas Getah Pelepah Pisang Ambon Musa Paradisiaca Var Sapientum Terhadap Pertumbuhan Bakteri Staphylococcus aureus, Pseudomonas aeuroginosa dan Escherichia coli. Biologi FMIPA Universitas Hasanuddin. Makassar. 
Sabir, A. 2003. Pemanfaatan Flavonoid Di Bidang Kedokteran Gigi. Dental Jurnal. 36 (1): 81-87.

Saraswati, Nur Faradila. 2015. Ekstrak Metanol Kulit Pisang Ambon Muda (Musa paradisiaca L.) Sebagai Antimikroba Terhadap Bakteri Escherichia coli Secara In Vitro. Fakulitas Kedokteran dan Ilmu kesehatan. UIN Syarif Hidayatullah. Jakarta. Diakses tanggal 15 Februari 2017.

Sari, Yeni Dianiat, Siti Nur Djannah, Laea Hayu Nurani. 2010. Uji Aktivitas Antibakteri Infusa Daun Sirsak (Annona Muricata L.) Secara In Vitro Terhadap staphylococcus aureus Atcc 25923 dan escherichia coli Atcc 35218 Serta Profil Kromatografi Lapis Tipisnya. Kes Mas, 4 (3): 144-239.

Supartono. 2006. Pemeriksaan Staphylococcus aureus Pada Organ Dalam Hewan dan Bahan Makanan. Pusat Penelitian dan Pengembangan Peternakan. Diakses tanggal 10 Februari 2017.

Wardini, ladisia agata, dan Siti Sulandjari. 2017. Pengaruh Penambahan Tepung Kulit Pisang Kepok dan Kulit Jeruk Nipis Terhadap Hasil Lulur Tradisional. e-Journal, 6 (1): 73-80.

Widyasari, R. 2007. Aplikasi Penambahan Flokulan Terhadap Pengolahan Sari Buah Jambu Mete (Anacardium occidentale, L.). Fakulitas Pertanian. IPB. Bogor. Diakses tanggal 15 Februari 2017. 